\title{
Administrative and Legal Consequences of the Spread of Coronavirus Covid-19: The Russian and Foreign Aspects
}

\author{
Savostin A.A. ${ }^{1, *}$ Admiralova I.A. ${ }^{2}$ Kashkina Ye.V. ${ }^{2}$ \\ ${ }^{1}$ Department of private law, Institute of public administration and law, State University of management, Moscow \\ 109542, Russian Federation \\ ${ }^{2}$ Center for training police officers for public order units, All-Russian Institute for Advanced Training of Officers of the \\ Ministry of Internal Affairs of Russia, Domodedovo 142007, Russian Federation \\ *Corresponding author.Email: mpkr@mail.ru
}

\begin{abstract}
The manuscript analyzes the administrative and legal consequences of the spread of a new coronavirus infection, both in the Russian Federation and abroad. After the detection of coronavirus infection, the leaders of the legislative bodies of many countries began to actively draft and adopt regulations aimed at preventing the spread of the new disease. Not only restrictive acts were adopted, but also penalties for violation of these measures, up to and including criminal prosecution. The article discusses the main directions of improving Russian legislation in the field of restricting the right of citizens to move during the period of introduction of increased security measures or a state of emergency (situation). The issue under consideration is essentially of high relevance and legal significance. The relevance of this topic is beyond doubt. Currently, there are a huge number of lawsuits on the fact of illegal restriction of freedom during the active phase of the spread of coronavirus infection in the courts of the Russian Federation and in other foreign countries. To clarify the goals set, it is necessary to adopt primary normative acts establishing the right of regions to restrict the movement of citizens. The authors have made an attempt to interpret the existing federal and regional regulatory legal acts, as well as regulatory legal acts of foreign countries. Extraordinary proposals aimed at improving the administrative and legal regulation of restricting the rights of citizens to free movement in the territory of the Russian Federation have been put forward.
\end{abstract}

Keywords: coronavirus, infection, legal regulation, offense, administrative proceedings, foreign experience, restriction, free movement

\section{INTRODUCTION}

In 2020, the world community, for the first time in the 21 st century, faced a large-scale epidemic of a new previously unknown type, which poses a threat to the life and health of millions of citizens. It turned out to be a dangerous fatal disease - a new coronavirus infection (COVID 19). In various countries, government bodies began to forcefully adopt regulatory legal acts to prevent the spread of the new coronavirus infection. First of all, legal acts began to be adopted restricting the movement of citizens in public places. New sanctions began to be introduced, both administrative and criminal.

In the Russian Federation, in order to prevent the spread of coronavirus infection, the Decree of the President of the Russian Federation dated 02.04.2020 No. 239 "On measures to ensure the sanitary and epidemiological wellbeing of the population on the territory of the Russian Federation in connection with the spread of a new coronavirus infection (COVID-19)" was originally issued.
According to this decree, the leaders of the constituent entities of the Russian Federation were charged, based on the sanitary and epidemiological situation and the peculiarities of the spread of the new coronavirus infection (COVID-19) in the constituent entity of the Russian Federation, to ensure the development and implementation of a set of restrictive and other measures, as well as to establish a special procedure for the movement of persons in the corresponding territory. and vehicles, except for vehicles carrying out interregional transportation [1].

\section{RESEARCH METHODS}

The methodological basis of this study was formed by general scientific methods of cognition, including the principles of objectivity, consistency, induction, deduction, etc. Along with the general scientific methods of cognition, following private scientific methods were used: descriptive, linguistic, comparative legal. The disclosure of the topic under study is made from the standpoint of general scientific methods (sociological, systemic, 
structural-functional, concrete historical, statistical), general logical methods of theoretical analysis, private scientific methods (comparative jurisprudence, technical and legal analysis, concretization, interpretation). In connection with the foregoing, a comparative study of the state of Russian legislation to prevent the spread of a new coronavirus infection seems relevant. Comparison and analysis will be carried out on the basis of foreign experience in legal regulation of restrictions on the rights of citizens to free movement in connection with the identification of a new dangerous disease in certain territories.

\section{RESEARCH RESULTS}

Federal Law No. 99-FZ dated April 1, 2020 amended the Code of Administrative Offenses of the Russian Federation, according to which administrative responsibility is established for violation of legislation in the field of ensuring the sanitary and epidemiological wellbeing of the population, committed during an emergency regime or in the event of a threat of the spread of a dangerous disease or restrictive measures (quarantine), as well as for failure to comply within the prescribed period of time with the requirements of the body carrying out the federal state sanitary and epidemiological supervision to carry out sanitary and epidemiological measures. The corresponding amendments were made to Art. 6.3 of the Administrative Code of the Russian Federation. These violations entail the imposition of an administrative fine on citizens in the amount of RUR 15 th. to RUR 40 th. [2] Chapter 20 of the Code of Administrative Offenses of the Russian Federation was also supplemented by Art. 20.6.1, which establishes administrative responsibility for violation of the self-isolation regime, namely, for failure to comply with the rules of conduct when the high alert regime is introduced in an area where there is a threat of an emergency, or in an emergency zone. Responsibility for the indicated offense will arise if these actions do not fall under the provisions of Art. 6.3 of the Administrative Code of the Russian Federation (taking into account the above new amendments) [3].

Subsequently, Federal Law No. 100-FZ dated April 1, 2020 entered into force, which also strengthened criminal liability for violation of sanitary and epidemiological rules, if it led to a mass illness or poisoning of people, or if the culpable actions created a threat of such consequences. In addition, amendments have been made to Art. 13.15 Administrative Code of the Russian Federation. For legal entities, a fine amounting from RUR $1.5 \mathrm{mln}$ to RUR 3 $\mathrm{mln}$ is established with or without confiscation of the subject of an administrative offense for dissemination in the media or information and telecommunication networks under the guise of reliable messages of knowingly false information about circumstances that pose a threat to the life and safety of citizens, and (or) on measures taken to ensure the safety of the population and territories, methods and ways to protect against these circumstances [4].
In addition, most European states have adopted regulatory legal acts aimed at preventing the spread of coronavirus infection. At the same time, quarantine was introduced in Europe due to the coronavirus pandemic in certain territories.

In Austria, for example, in order to combat the spread of COVID-19, Federal Chancellor Sebastian Kurz introduced an emergency regime in the country from March 16, 2020. Citizens are allowed to leave the house only in three cases: to get to work, buy food or help those who need it. The army has been mobilized, patrols are on duty in the streets, which have the right to stop anyone and check documents. For violation of the quarantine regime, a fine of $€ 2,180$ was introduced [5].

In Spain, the country's authorities have introduced a state of emergency for 15 days, obliging all residents to strictly adhere to quarantine. Violators face fines ranging from $100 €$ th. to 600 th., as well as imprisonment for a period of three months to a year. Italy was the first European country to impose such tough restrictions. To leave the house, one must fill out a special form, indicating the reasons for the violation of the quarantine regime. Those who violate these rules face arrest for up to three months or a fine of up to $€ 206$. In Israel, due to a sharp outbreak of coronavirus infection, Prime Minister Benjamin Netanyahu declared a state of emergency in the country on March 19. Citizens are prohibited from leaving home without a valid reason. For violation of the regime, a fine is imposed, and if the quarantine is violated again imprisonment for up to three years [6].

In Norway, the country's authorities announced the introduction of a fine for violation of the rules of home quarantine or home isolation of 20 thousand krones (more than $1,700 €)$. There is also a 15 -day prison sentence. In Poland, fines of up to PLN 5 th. (about 1,200 €) have been introduced for non-compliance with quarantine, as well as for hiding information about the disease. In France, since March 17, 2020, strict quarantine has been introduced in the country. Leaving the house was only allowed to go to the store, pharmacy and work. Every person leaving the house must have an explanatory note with him, the form of which can be downloaded on the website of the Ministry of Internal Affairs or written by hand [7]. For going out into the street without a valid reason, they are punished with a fine of $135 €$, for a repeated violation - from 30 th. $€$.

In Croatia, citizens violating quarantine are fined 8 thousand kunas (about 1,100 €), and in the Czech Republic for violating the isolation regime, they face a fine of 3 million krones (about 120 th. $€$ ) [8].

Specifically in the Russian Federation there were no such high fines as in Europe, under Art. 20.6.1 of the Code of Administrative Offenses of the Russian Federation, for example, it was possible to lie down citizens from RUR 1 th. to RUR 30 th. As a rule, the lowest fine was imposed upon initial detection [1]. During the introduction of the high-risk regime, the courts of the Russian Federation began to receive a huge number of administrative cases for violation of the regime of restrictive measures. At the same time, citizens appealed to the courts, believing that 
such restrictive measures were taken in excess of the powers of the subjects of the Russian Federation. The applicants disputed the legality of the issuance by the regional authorities of normative acts restricting the right of movement, which is guaranteed by the Constitution of the Russian Federation (Art. 27).

The arguments of the administrative plaintiffs can be summarized in three main points:

firstly, the controversial measures limit freedom of movement (after all, one can leave home only to go to work, urgently see a doctor, take out the trash, walk the dog and buy food, and somewhere else twice a week). And according to Art. 56 of the Constitution of the Russian Federation, freedom of movement can be limited only under conditions of a state of emergency, which has not been introduced in the capital;

secondly, the controversial measures violate the right to privacy and personal secrets, because when planning to leave homes for going somewhere, Muscovites are obliged to inform the authorities in advance, transferring their personal data, as well as their private secrets - goals, route and other details of the trip. And the right to inviolability of private life shall not be limited at all, even if under martial law or a state of emergency;

thirdly, the controversial Decrees were issued in violation of the established procedure - such acts (on the protection of the rights and freedoms of citizens) shall enter into force no earlier than 10 days after official publication, and these came into force immediately after publication.

\section{DISCUSSION OF FINDINGS}

The Universal Declaration of Human Rights, adopted by the UN General Assembly on December 10, 1948, states: "All people are born free and equal in dignity and rights. They are endowed with reason and conscience and should act towards each other in a spirit of brotherhood". The basic law of the Russian Federation proclaims: "Basic human rights and freedoms are inalienable and belong to everybody from birth" [9]. Therefore, a person acquires the right to freedom of movement by virtue of birth, however, being a fundamental right in a person's life, it is not absolute, i.e. that right that cannot be limited under any circumstances [10].

Thus, in the Russian Federation, the right to freedom of movement is enshrined in article 27 of the Constitution, which states that "everyone who is legally on the territory of the Russian Federation has the right to move freely, choose a place of stay and residence. Everyone can freely travel outside the Russian Federation. Citizens of the Russian Federation shall have the right freely to return to the Russian Federation" [11].

In the early 2000 s, many scholars actively discussed the grounds for restricting citizens' rights to free movement. At that time, the authorities limited the right of movement on the basis of the adopted regional laws, and could also restrict the right of movement due to the lack of, for example, registration or registration at the place of stay.
Thus, Avakyan SA, as well as many other authors, note that "there are no fundamental differences between the domicile registration and the registration" [12]. But Ye.I. Kolyushin [11] sees the difference between the domicile registration and the registration in the fact that "the domicile registration is a measure of compulsory accounting and registration, the absence of which entails the absence of rights or limitation of the legal capacity of a person, and registration is an act of free expression of the will of a citizen when choosing a place of residence, the absence of which does not connected with the limitation of human legal capacity". One should disagree with this, since in practice, unfortunately, the lack of registration leads to many violations of the rights of citizens [13].

It is worth remembering another way of limiting the constitutional right to free choice of place of stay and residence: these are regulations issued in this area of the constituent entities of the Federation [14], which violate federal legislation and thereby infringe upon the rights of citizens to choose a place of stay and residence, creating they have numerous obstacles to registering in a new place, in terms of establishing registration advantages for certain groups of citizens, setting deadlines for registration at the place of stay and residence, etc.

\section{CONCLUSIONS}

Analyzing the above, we can make an intermediate conclusion that freedom of movement has fragile boundaries of what is permissible, and the state should monitor the mechanism of the right to freedom of movement, established over the years, including the minimum restrictions necessary for the correct development of a democratic society.

Based on the results of consideration of administrative applications, Russian courts completely dismissed the claim [15], noting that:

freedom of movement is not absolute, and it can be limited even without the introduction of a state of emergency, by ordinary federal law - to the extent necessary to protect the health, rights and legitimate interests of others, to ensure the country's defense and state security;

and the federal law - the Law of the Russian Federation of June 25, 1993, No. 5242-1 "On the right of citizens of the Russian Federation to freedom of movement, selection of place of stay and residence within the Russian Federation" - just allows restricting freedom of movement in certain territories and settlements, where, in the event of a danger of the spread of infection, special conditions and modes of residence of the population and economic activity have been introduced;

it is precisely such a regime - high alert (HA) - that was obviously introduced in Moscow, while the RF Law on the Protection of the Population from an Emergency Situation not only gives the region the right to introduce such a regime, but also, in case of an HA, gives the head of liquidation an emergency (that is, the highest official of a constituent entity of the Russian Federation) the right to 
restrict the access of people and vehicles to the territory where there is a threat of an emergency;

and the concept of "restricting access" also includes the concept of "restricting the movement of people and vehicles on the territory where there is a threat of an emergency";

therefore, the right to freedom of movement is legally restricted;

Thus, at present there is no clear legal regulation of the grounds for restricting the rights of citizens to free movement during the period of restrictive measures. It is not entirely clear which authorities - federal or regional should adopt such restrictive regulations. Consequently, in order to eliminate contradictions between federal and regional legislation, to concretize the grounds for restricting the rights of citizens, it is necessary to enshrine in the main law of the country - the Constitution of the Russian Federation, provisions and grounds establishing restrictive measures for the free movement of citizens. It is also necessary to establish penalties only at the federal level, otherwise contradictory judicial practice may develop in different constituent entities of the Russian Federation within the same country.

\section{REFERENCES}

[1] From April 1, administrative liability was established for violation of quarantine and self-isolation regime, Garant, Electronic resource, 09/10/2020.

[2] Yu.A. Savinov, V.N. Kirillov, E.V. Taranovskaya, The Impact of the Chinese Coronavirus on the World Economy and Trade, International Economics. 2020, no. 2, pp. 63-71.

[3] G.P. Voronin, The situation with the coronavirus. EDI's perspective, Standards and Quality, 2020, pp. 1-5.

[4] Behsudi, China warns against virus-related trade restrictions, Electronic resource.

[5] Coronavirus (Covid-19), Information for Exporters, Electronic resource.

[6] Potential impact of coronavirus on international supply chains, Electronic resource.

[7] S. Sun, N. Sharman, Impact of the Coronavirus outbreak on International Trade Involving China, Electronic resource.

[8] Wrede, How will the coronavirus aff ect the world economy? Electronic resource.

[9] Universal Declaration of Human Rights, adopted by the UN General Assembly on December 10, 1948, SPS "Consultant-Plus".
[10] N. Lum, I. Clayton, Novel coronavirus outbreak: implications for international trade and shipping, Electronic resource.

[11] E.I. Kolyushin, Constitutional Law of Russia. Course of lectures, Gorodets, 2006. P. 416.

[12] S.A. Avakyan, Constitutional Law of Russia: Curriculum: in 2 volumes, T. 1, 2nd ed., Revised and additional, Lawyer, 2006, P. 719.

[13] D.G. Vasilevich, Freedom of movement in Belarusian legislation in the system of other human rights and freedoms, Journal of Russian Law, 2007, No. 7, pp. 122-129.

[14] M.V. Kostennikov, E.V. Kashkina, K.A. Sultanov Perspectives of Administrative Legal Proceedings Improvement in Conditions of Digitalization, Advances in Economics, Business and Management Research, volume 137, Available Online May 2020.2 DOI: https://doi.org/10.2991/aebmr.k.200502.125

[15] Decision of the Moscow City Court dated April 28, 2020 in case No. 3a-3877/2020, SPS "Consultant-plus". 